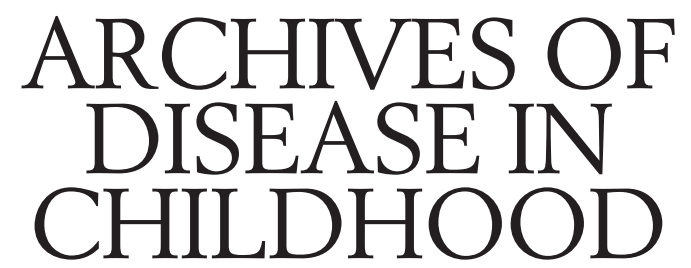

The fournal of the Royal College of Paediatrics and Child Health

\title{
Annotations
}

\section{Good enough parenting for all children - a strategy for a healthier society}

Over recent years there has been a crescendo of political and public concern about a variety of issues which taken together suggest an impending crisis in our society. These include a rising incidence of ${ }^{\star}$ crime, violence, and delinquency and an ever increasing prison population, together with concern about deteriorating discipline in many schools. In addition there is increasing evidence that family breakdown through parental separation, divorce, or single parenthood has deleterious effects on the lives of children. ${ }^{1}$ Drug addiction and homelessness are increasing, as is the number of children living in conditions of poverty. ${ }^{2}$ There remains a continued background of concern about the high incidence of child abuse and neglect in all its forms, and confusion about society's apparent failure to manage it effectively. ${ }^{3}$ ( ${ }^{\star}$ Recorded crimes per year rose from 1.6 million offences recorded by police in 1970 to 5.6 million in 1992; the figure for total crimes in 1992 is estimated at about 15 million pa.)

Over the last 10 years society has had to face the following dramatic examples that have each in their separate ways symbolised some form of failure in society: (a) The death of Jamie Bulger at the hands of two 10 year old boys; (b) the murder and abuse of many children carried out over a long period of time by Fred and Rosemary West; (c) the Dunblane massacre; (d) the stabbing of the headmaster Philip Lawrence outside his school, and his wife's call for a national revival of morality; and (e) the apparently racist killing of Stephen Lawrence.

All these dramatic examples have increased the sense of crisis in society. Unfortunately in none of the above cases has there been a proper analysis of the lessons that can be learnt for the good of society.

The response of politicians of both main parties has been to compete as to who can sound toughest on crime, who will build the most prisons, and keep the most prisoners locked up the longest. When not being purely punitive, politicians unite in calling for a need to strengthen "family values". There is also much talk about various forms of symptomatic treatment, such as punishing parents for their children's wrongdoing and introducing "morality" into the National Curriculum. Yet, "one cannot hope to abolish suicide by legislating against the existence of tall buildings and the sale of rope"!
It is unfortunate that politicians in their resort to sound bite solutions should ignore the vast amount of knowledge that is available which could form the basis for a rational and cost effective strategy for a healthier society. In this article we intend to concentrate on the issues of child rearing. We accept that wider economic and social issues are also involved (such as the problems of unemployment, poverty, homelessness, and deprivation) but these are outside the scope of the article. The concept that improving child rearing is a vital recipe for the prevention of delinquency and crime in later life is not new. For a fuller development of this theme we highly recommend a publication on this topic by the Family Studies Centre which reviews much of the extensive literature on the subject. ${ }^{1}$ In this article, we are concentrating on an analysis of the concept of "parenting".

It is reasonable to start from the premise that the needs of children are best met by being raised in "families". However, it is naive to assume that as long as all children are brought up in their natural/biological families there will be no problems. One of the common threads linking most of the above examples is how spectacularly natural families can fail to provide normal happy childhoods. There is nothing foolproof or sacrosanct about natural families as a recipe for a healthier society.

Families (whether natural or substitute) can only meet the needs of children if they provide them with good (or "good enough") parenting.

\section{Concept of good enough parenting}

To the best of our knowledge, the concept of "good enough parenting" was first used by Winnicott. ${ }^{4}$ In doing so he was recognising that it is unhelpful and unrealistic to demand perfection of parents, and to do so undermines the efforts of the vast majority of parents who are in all practical respects "good enough" to meet their children's needs. Of course, society has already had to face up to the fact that some parents are "not good enough" by recognising the problem of child abuse and neglect and setting up structures to deal with it, and where appropriate, providing alternative parenting. 


\section{Concept of parenting}

Despite its frequent use the concept of parenting is difficult to define. We use it to refer to a relationship, a process, and a group of activities. "To parent" is an active verb which denotes positive activities undertaken by parent figures towards children. Although the noun "parent" usually implies a natural or biological parent, it should be stressed that "good enough" and indeed "super" parenting can be delivered by non-biological parent figures.

Anyone concerned with the care of a child can be seen as part of the parenting process. Anyone concerned with any part of a child's care, control, and development in any setting can be said to be engaging in parenting. Thus grandparents and other members of the extended family, family friends and neighbours, school teachers, family aides, community workers, and even doctors and nurses can all be seen as part of the parenting process.

Far from widening the definition of parenting so far that it becomes meaningless, we believe that it is essential to recognise the wide continuum of parenting a child needs as he or she moves through childhood and adolescence to adulthood. Even adults have a need for parenting as every parent of "grown up children" knows.

Importance of parenting and the needs of children It is generally accepted that the needs of children are at their most intense in the first five years of life when they are at their most dependent on parent figures for physical and emotional nurture and protection. Good enough parenting delivered consistently over this critical period enables attachment and fosters the child's sense of basic security, which is essential for subsequent mental health and self esteem. Once acquired, these attributes constitute a firm foundation for the rest of childhood and adult life.

The crucial role of secure attachment to a parent/parent figure in this context was highlighted as long ago as 1951 by John Bowlby ${ }^{5}$ for whom the development of this theory constituted his life work. In general, the basic tenets of attachment theory have stood the test of time, although Rutter ${ }^{6}$ has summarised important changes of emphasis over the 30-40 years since Bowlby first proclaimed its importance. Tizard, in a study of adoption of older children, showed that although the concept of a critical period for attachment remained valid, the duration of this period can extend into later childhood. ${ }^{7}$

Rutter also stressed that the extent to which distortions of attachment impacted on a child varied as a result of the child's temperament, genetic endowment, and special needs.

\section{Components of good enough parenting}

We can define good enough parenting as a process that adequately meets the child's needs, according to prevailing cultural standards which can change from generation to generation. Of course all children need physical care, nutrition, and protection. Over and above these basics, the child's emotional needs can be regarded under the following three headings: (1) love, care, and commitment; (2) consistent limit setting; (3) the facilitation of development.

It is vital to realise that the long term provision of all three aspects of parenting is essential to ensure that the child grows up into an emotionally secure, fully developed, and competent adult.

(1) LOVE, CARE, AND COMMITMENT

We make no apologies for the use of the word "love". It is ironic that this most vital and easily understood concept is hardly to be found in the scientific literature. Children need to feel that they are loved consistently and unconditionally, and attachment behaviour is the natural consequence of this. If a child is severely emotionally deprived throughout early childhood, there is a risk of developing Bowlby's "affectionless psychopathy" with all the social handicap that will result for both the individual and society. If the deprivation is partial, the child will be at risk of developing insecure attachments with subsequent disturbance of social and emotional relationships.

Unfortunately some child care professionals seem to have lost sight of the crucial importance of "emotional deprivation" as highlighted by Bowlby. In child protection work the concept has been virtually lost, or subsumed within the category "emotional abuse", which is really quite different, being a positive rather than a negative form of abuse. Paediatricians can document failure of physical growth in severe cases of non-organic failure to thrive. They (and child psychiatrists) are less good at recognising and acting upon "emotional failure to thrive". Perhaps we need the equivalent of a blood test for "serum love", which when low levels are recorded would indicate the need for urgent replacement therapy.

\section{(2) CONTROL/CONSISTENT LIMIT SETTING}

Control is concerned with setting and enforcing boundaries to help the child in his/her dealings with the outside world. Boundaries must be set to show what behaviour is unacceptable, with due allowances made for developmental stages. Enforcement involves clear actions of either reward or disciplinary sanctions to ensure compliance within these boundaries.

"Good enough" control requires the setting of reasonable boundaries which are enforced in a consistent yet loving way so that the child eventually accepts the reality of the boundaries and incorporates them in its actions. Ideally the child learns to live within generally acceptable boundaries for behaviour, that is becomes socialised. If the boundaries are inherently unreasonable or control is applied inconsistently or too punitively this will be damaging to the child's development. Many habitual delinquents have been the subject of an indulgent lack of discipline interspersed with unpredictable and sudden outbursts of harsh discipline.

\section{(3) FACILITATION OF DEVELOPMENT}

This third aspect of parenting involves fostering the child's development to enable the child to fulfil his/her full potential. This involves every area of functioning, from the physical and intellectual to the moral, aesthetic, and spiritual. The child has a fundamental need for a secure base from which to explore his/her environment. "Good enough" care involves providing rich and varied stimulation in early childhood followed by involvement and support for the child throughout later years until adulthood is reached.

\section{Consequences of not good enough parenting}

Children can suffer deficiencies in any or all of the above aspects of parenting, and considerable overlap is common. However, if one postulates pure deficiencies of each modality in isolation the following patterns would be expected.

TYPE A

Defective loving care and commitment throughout early and middle childhood is a barrier to normal attachment. This will be expected to produce an insecure personality with low self esteem, and problems with peer relationships, marriage, and parenting. One or more types of personality disorder may be the consequence, ${ }^{6}$ with the most extreme result being "affectionless psychopathy". 
TYPE B

Children brought up without controls or with totally confusing controls are at risk of future conduct disorder, delinquency, and criminal behaviour. ${ }^{8}$

TYPE C

Children whose early development is blighted by neglect and understimulation are at risk of subsequent educational failure and social handicap.

Of course, many children are subjected to a mixture of all three forms of defective parenting and end up with a combination of any of these end results. Each of these three end results has been shown to be strongly associated with subsequent criminal behaviour.

\section{Possibility of predicting criminality}

If we consider the above end results of "not good enough" parenting, together with evidence from criminological literature, it becomes apparent that there is strong evidence for the concept that juvenile delinquency and adult criminal activity can be predicted. If criminal behaviour can be predicted early enough and its aetiology understood in sufficient depth, then there should be excellent opportunities for a preventive strategy. This is arguably the current state of affairs regarding crime, but what is lacking is a consensus on how to intervene effectively and where the resources are to come from.

Much of the best evidence in the UK comes from the Cambridge Study in Delinquent Development by Farrington and West. ${ }^{9}$ They found that one of the best predictors of later delinquency was the teacher's assessment of "troublesomeness" at the age of 8-10 years. Nearly half of a series of recidivist delinquents had been previously identified as troublesome by their primary school teachers.

Similarly evidence from Norway has shown that $60 \%$ of known school bullies had committed a criminal offence by the age of 24 , and that bullies were four times likelier than non-bullies to become recidivist criminals. ${ }^{10}$ Poor parenting was seen as the basic underlying cause of these problems. However, such examples of prediction apply to a relatively late state in a child's development. If prevention is possible, logic dictates that the sooner it can be instituted the greater the chances of success. Accordingly, predictive factors that can be identified earlier in childhood are needed. The Cambridge study again yields valuable evidence, to the effect that four other factors were found to be strongly and independently associated with future delinquency, each to roughly the same extent. ${ }^{9}$ These were: (i) poor parenting; (ii) economic deprivation; (iii) family criminality; and (iv) educational failure.

Economic deprivation is obviously important but is outside the scope of this article. Family criminality does not lend itself easily to a preventive strategy (other than adoption!) Educational failure manifests itself late in a child's development, and a preventive strategy based on this should be aimed at the preschool period. Anyway, much of the educational failure that is preventable is probably secondary to poor parenting.

This leaves poor parenting itself as the single factor most likely to respond to a preventive strategy, because it is (a) easily identified early in a child's life and (b) very likely that its association with subsequent criminality is a causative one (see above).

Evidence from the Newcastle 1000 Family Study endorses this view. ${ }^{11}$ This showed a strong association of criminal behaviour in adults with their having been exposed to "multiple deprivation" as children. However, it was found that children from deprived backgrounds who did not acquire a later criminal record had almost all received "good parenting". The authors concluded "Good parenting protects against the acquisition of a criminal record".

\section{Economic arguments for prevention by targeting parenting}

Presumably one of the functions of the criminal justice system is to prevent crime by the deterrent effect of detecting crimes and punishing criminals. However, it has failed to prevent a $300 \%$ increase in crime over the last 30 years so by any standards it is a near total failure. Unfortunately it is also an extremely expensive failure.

A Home Office working party has attempted to quantify the total economic cost of crime to society. ${ }^{12}$ The official costs of the criminal justice system in 1992 were $£ 9$ billion, a $100 \%$ increase since 1978 . If the costs to victims and property are included the cost of crime is thought to roughly equal the entire cost of running the National Health Service ( $£ 18$ billion in 1988 ). Yet staggeringly, only $3 \%$ of offences committed by adults result in a perpetrator being cautioned or prosecuted. ${ }^{13}$ The figures for juvenile crime are probably even lower. The Audit Commission report Misspent Youth has recently highlighted this gross misdirection of public money. ${ }^{14}$

While many of the measures needed for a preventive strategy will require considerable resources, in view of the expensive failure of the criminal justice system, it is not a question of "Can we afford a preventive strategy" but "Can we afford to carry on the way we are going?".

Although a preventive strategy aimed at providing better parenting for all vulnerable children in society will be expensive, it is likely to be vastly more cost effective than continued reliance on the criminal justice system.

\section{Governments as parents of society}

Governments should be regarded as the parents of society. A "not good enough parent" of a government will show a general lack of care for the whole population, will put its own interests first, will discriminate against some of its "children" in favour of others, and will react excessively punitively when some if its children misbehave. A "good enough parent" of a government will truly care for all its children and will seek to promote their welfare, while still being firm and fair in applying sanctions for unacceptable behaviour. It will also be interested in using available knowledge to understand and ameliorate problems arising in society, like a well meaning family accepting they have problems and seeking appropriate help. A preventive strategy aimed at promoting good enough parenting is the treatment that British society would seem to need as a matter of urgency. A central aim should be to instil the idea that we are all responsible for society's children.

\section{Good enough parenting for all children}

We offer the following policy proposals for consideration as part of a preventive strategy.

Firstly, it should be recognised that the vast majority of parents in society are already providing good enough parenting, and accordingly a strong degree of targeting is in order. Health visitors are already perfectly capable of detecting poor parenting in early childhood, but they lack support for effective intervention. (The features of the whole spectrum of parenting are well described by Cooper. ${ }^{15}$ )

The majority of not good enough parents should hopefully benefit from early and intensive support, enabling them to become good enough parents. Supportive measures could involve: (a) universally available nursery placements; (b) well resourced and expert social work help/family aides/respite care; (c) parenting classes for teenage parents; (d) easier access to child guidance/child 
psychiatry services; (e) early referral from nursery/infant school for children with remediable problems such as attention deficit hyperactivity disorder, dyslexia, and severe behavioural problems; (f) effective antibullying strategies in schools; and ( $\mathrm{g}$ ) strategies for prevention of teenage pregnancies.

The school health service as a whole has a potentially crucial role in the development of the above strategies. (In this context it is extremely worrying that in many areas school health services are currently under threat.) However, considerable resources will also be needed for health visiting, social services, child psychiatry, and education to reverse the low morale and near despair that years of underfunding have caused. Hopefully this will allow the professionals to recharge their batteries to the extent that they can tackle these problems effectively on a populationwide basis. It is essential that multiagency responses are coordinated so that identification of problems by health visitors, school doctors, etc can lead to effective intervention.

Important and innovative work by Davies et al has shown that it is possible to achieve significant improvements in families in areas of high deprivation in London. ${ }^{16}$ This programme involved extra training and supervision of health visitors and school doctors and did not require major new resources. Extending programmes like this on a nationwide basis would seem a practical way of beginning to tackle the major task we are considering.

Finally, society and professionals should face up to the fact that not all parents can respond to professional intervention to a degree sufficient to meet their children's needs. The Kempes' concept of "the untreatable family" is relevant here ${ }^{17}$ Society and social workers accept the need to remove severely battered or sexually abused children from their natural families for good. However, society finds it harder to accept that there is a far larger number of children who suffer significant harm from neglectful parenting to their detriment and to the future detriment of society. Most of these children never even get on to an at risk register, let alone have a protection/nurture plan drawn up. Child A in the Bulger case is a dramatic example. All the features of his emotional deprivation were well known to professionals for several years before the murder yet no action was taken. There is ample evidence that the condi- tions associated with poor parenting are becoming more widespread. ${ }^{18}$ There are strong hints that our politicians are at last waking up to the central importance of good parenting, as evidenced by the formation of the All-Party Parliamentary Committee on Parenting, and the recent document on parenting from the Labour Party. ${ }^{19}$ However, unless this leads to a coherent strategy supported by adequate resources, we seem doomed to continue current policies of "too little, too late".

M HOGHUGHI

Newcastle General Hospital,

Westgate Road,

Newcastle upon Tyne NE4 6BE

A N P SPEIGHT

Department of Paediatrics,

Dryburn Hospital, North Road,

Durham DH1 5TW

1 Utting D, Bright J, Henricson C. Crime and the family-improving child-rearing and preventing delinquency. London: Family Policy Studies child-rearing and pre
Centre, June 1993: 7 .

2 Spencer N. Poverty and child health. Oxford: Radcliffe Medical Press, 1996: $21-36$.

3 National Commission of Inquiry into the Prevention of Child Abuse. Childhood matters. London: Stationery Office, 1996.

4 Winnicott DW. The maturational process and the facilitative environment. New York: International Universities Press, 1965.

5 Bowlby J. Maternal care and mental health. Geneva: World Health Organisation, 1951

6 Rutter M. Maternal deprivation reassessed. Harmondsworth: Penguin, 1981. 7 Tizard B. Adopting older children. 1977.

8 Farrington D. Understanding and preventing youth crime. York: Joseph Rowntree Foundation, 1996.

9 West DJ, Farrington DP. Who becomes delinquent. London: Heinemann Educational, 1973.

10 Olweus D. Bully/victim problems among schoolchildren: basic facts and effects of a school based intervention programme. In: Pepler DJ, Rubin K, eds. The development and treatment of childhood aggression. Hillsdale, New eds. The development and

11 Kolvin I, Miller FJW, Scott D McI, Gratzanis SRM, Fleeting M. Continuities of deprivation. (ESRC/DHSS Studies in Deprivation and Disadvantages No 15) Aldershot: Avebury, 1990

12 Charity Commission. Government expenditure plan 1993-4. London: HMSO. (cm 2208.)

13 Barclay GC, et al. Digest 2: information on the criminal justice system in England and Wales. London: Home Office Research and Statistics Department, 1993.

14 Audit Commission for Local Authorities and National Health Services. Mis-spent youth: young people and crime. 1996.

15 Cooper C. Good-enough parenting - a framework for assessment. London: British Agencies for Adoption and Fostering, 1985: 55-80.

16 Davies H, Spurr P, Cox A, Lynch M, von Roenne A, Hahn K. A description and evaluation of a community child mental health service. Clinical Child Psychology and Psychiatry 1977;2:221-38.

17 Kempe H, Kempe RS. Child abuse. London: Fontana, 1978.

18 Hoghugi M. Parenting at the margins In: Dwivedi, K, ed. Enhancing parenting skills. Chichester: Wiley, 1997.

19 Labour Party. Parenting. London: Labour Party, 1996.

\section{Genetic aspects of Charcot-Marie-Tooth disease}

\section{Historical perspective and nomenclature}

In 1886 Drs Charcot and Marie of France and Dr Tooth of England described patients with an inherited form of peroneal muscular atrophy, characterised by a progressive weakness and atrophy of distal muscles, usually originating in the feet and lower legs and progressing to the hands and forearms - a disorder now known as Charcot-Marie-Tooth (CMT) disease. Early literature attested to the existence of several distinct disorders in addition to CMT disease, including Dejerine-Sottas syndrome (DSS) and RoussyLévy syndrome, but histopathological evidence combined with the advent of electrodiagnostic testing and molecular investigation have demonstrated that these syndromes are clinical variants of CMT disease.

The term CMT disease is now applied to a range of hereditary peripheral neuropathies, with a population prevalence of approximately one in 2500 , which are able to be differentiated at several levels. None the less, the noso- logy surrounding CMT disease remains confusing and is further confused by the term hereditary motor and sensory neuropathy (HMSN), introduced to describe a broad range of neurological disorders with both motor and sensory involvement.

\section{Classification of CMT disease}

NERVE CONDUCTION STUDIES AND PATHOLOGY

A major differentiating factor between the different forms of CMT disease is identified by electrophysiological examination and nerve pathology. The combined strengths of these assessments allow the subdivision of CMT disease into two major groups, termed CMT disease type 1 and type 2 (CMT1 and CMT2). ${ }^{12}$

CMT1(HMSNI) is the more common of the two and characterised by diffusely low nerve conduction velocities (NCVs), typically $<38 \mathrm{~m} / \mathrm{s}$, and the appearance of "onion bulbs" on peripheral nerve biopsy due to demyelination 
Table 1 Dominant type 1 and 2 CMT neuropathies. Where known, the genetic location, gene responsible, and genetic defect are indicated

\begin{tabular}{|c|c|c|c|c|c|c|}
\hline \multirow{2}{*}{$\begin{array}{l}\text { Peripheral } \\
\text { neuropathy }\end{array}$} & \multicolumn{2}{|l|}{ Clinical features } & \multirow[b]{2}{*}{ Inheritance } & \multirow{2}{*}{$\begin{array}{l}\text { Genetic } \\
\text { location }\end{array}$} & \multirow[b]{2}{*}{ Gene } & \multirow[b]{2}{*}{ Genetic defect } \\
\hline & Nerve pathology & $N C V s$ & & & & \\
\hline CMT1A & Demyelinating/onion bulbs & Reduced & $\mathrm{AD}$ & $17 \mathrm{p} 11.2$ & PMP22 & Duplication/point mutation \\
\hline СMT1B & Demyelinating/onion bulbs & Reduced & $\mathrm{AD}$ & $1 \mathrm{q} 21-\mathrm{q} 23$ & $\mathrm{P}_{0}$ & Point mutation \\
\hline CMT1C & Demyelinating/anon bulbs & Reduced & $\mathrm{AD}$ & Unknown & Unknown & Unknown \\
\hline CMT2A & Axonal & Preserved or slightly reduced & $\mathrm{AD}$ & $1 \mathrm{p} 35-\mathrm{p} 36$ & Unknown & Unknown \\
\hline CMT2B & Axonal & Preserved or slightly reduced & $\mathrm{AD}$ & $3 q 13-q 22$ & Unknown & Unknown \\
\hline CMT2C & Axonal & Preserved or slightly reduced & $\mathrm{AD}$ & Unknown & Unknown & Unknown \\
\hline CMT2D & Axonal & Preserved or slightly reduced & $\mathrm{AD}$ & $7 \mathrm{p} 14$ & Unknown & Unknown \\
\hline CMTX1 & $\begin{array}{l}\text { Demyelinating/onion } \\
\text { bulbs/axonal }\end{array}$ & Reduced & XLD & $\mathrm{Xq} 12-\mathrm{q} 13$ & $\mathrm{Cx} 32$ & Point mutation \\
\hline \multirow[t]{3}{*}{ DSS } & Hypomyelinating/onion bulbs & Severely reduced & $\mathrm{AD}$ & $17 \mathrm{p} 11.2$ & PMP22 & $\begin{array}{l}\text { Four copies PMP22/point } \\
\text { mutation }\end{array}$ \\
\hline & & & $\mathrm{AD}$ & $1 \mathrm{q} 21-\mathrm{q} 23$ & $\mathbf{P}_{0}$ & Point mutation \\
\hline & & & $\mathrm{AD}$ & 8qter & Unknown & Unknown \\
\hline HNPP & Demyelinating/tomaculi & Reduced & $\mathrm{AD}$ & $17 \mathrm{p} 11.2$ & PMP22 & Deletion/point mutation \\
\hline
\end{tabular}

$\star \mathrm{AD}=$ autosomal dominant $\mathrm{XLD}=\mathrm{X}$ linked dominant.

and remyelination of the nerve. CMT2 (HMSNII) on the other hand is characterised by normal or near normal nerve conduction velocities and a decreased number of myelinated axons. While there is no evidence of demyelination and remyelination in CMT2, there are signs of marked axonal degeneration.

Patients with Dejerine-Sottas syndrome (HMSNIII) have markedly reduced $\mathrm{NCVs}^{1}$ and at peripheral nerve biopsy demyelination and onion bulb formation, similar to that in CMT1, is found in addition to evidence of hypomyelination.

\section{CLINICAL FEATURES}

The two major forms of CMT disease (CMT1/CMT2) are clinically very similar, with both motor and sensory nerve function impaired. The distal muscle weakness described above may be obvious from an early age as an abnormality of gait or clumsiness in running. Other typical features include weakness at the ankle, steppage gait, and the characteristic pes cavus deformity of the foot. Generally, the clinical features of DSS overlap with a severe CMT1 phenotype with patients demonstrating a chronic and progressive motor and sensory neuropathy, but with an onset usually in infancy or early childhood.

Hereditary neuropathy with liability to pressure palsies (HNPP) describes a neuropathy which causes nerve palsies and sensory dysfunction following minor nerve trauma. These palsies dissipate but a slowly progressive neuropathy is evident in patients. Nerve pathology demonstrates the typical demyelination and remyelination observed in CMT1 in addition to multiple sausage shaped focal thickenings (tomaculi) of the myelin sheath. ${ }^{3}$

\section{Molecular basis of CMT disease}

The clinical heterogeneity of CMT disease is paralleled at a genetic level, with autosomal dominant and recessive and $\mathrm{X}$ linked dominant and recessive families documented. Recent molecular investigations have given further insight into the heterogeneity of CMT disease and, in some instances, allowed the localisation of defective genes (table 1).

\section{CMT1}

CMT1 is acknowledged as the most common form of these peripheral neuropathies and consequently genetic linkage studies have focused predominately on these families, resulting in the identification of three subgroups of families, each with a distinct genetic locus. ${ }^{4}$ In each of these groups the disorder is transmitted in an autosomal dominant manner. The first subgroup, CMT1A, maps to chromosome $17 \mathrm{p} 11.2$ and is caused, in the majority of cases, by a duplication of $1.5 \mathrm{Mb} \mathrm{DNA}$, encompassing the peripheral myelin protein 22 ( PMP22) gene. The duplication is caused by unequal crossing over via two repeat sequences located at the proximal and distal end of the duplicated segment. This duplication event associated with CMT1A accounts for $70-85 \%$ of CMT1 cases. The reciprocal product of this crossover (deletion of a copy of $P M P 22$ ) has been shown to be the molecular defect in the majority of HNPP cases. $^{3}$ Point mutations within PMP22 may also account for a small proportion of CMT1 or HNPP cases, rather than duplication or deletion. A proportion of the remainder of CMT1 cases is accounted for by point mutations in a second myelin protein, peripheral myelin protein zero $\left(P_{0}\right)$, which maps to $1 \mathrm{q} 21-\mathrm{q} 23$. This locus has been designated CMT1B. Heterozygous mutations within either of these genes have been identified in DSS patients, leading to DSS now being classed as a severe CMT1 variant. ${ }^{4}$

In addition CMT1 families shown not to be linked to either the CMT1A or CMT1B loci indicate that a third CMT1 gene (CMT1C) exists. No candidate region has yet been identified in these patients, but the identification of a DSS locus on chromosome $8^{5}$ leads one to speculate that this may represent the CMT1C locus.

CMT2

Genes associated with the axonal form of CMT disease have, to date, been assigned to at least three loci. ${ }^{6}$ Again, in each group the mode of inheritance is autosomal dominant. CMT2 has been mapped on the basis of linkage studies to chromosomes 1p35-36 (CMT2A), 3q13-22 (CMT2B) and 7p14 (CMT2D). A fourth CMT2 form, distinguished clinically on the basis of diaphragm and vocal cord weakness, in addition to an axonal neuropathy, has also been reported. This group, designated CMT2C, has been shown to be genetically distinct from CMT2A and CMT2B.

CMTX1

Clinically, X linked dominant CMT disease resembles the CMT1 phenotype-reduced NCVs and a demyelinating pathology. However, expression of the disease in carrier females is variable ranging from asymptomatic with normal NCVs to disabling manifestations with reduced NCVs.

Linkage studies placed the $\mathrm{X}$ linked dominant CMTX locus in a $1 \mathrm{cM}$ interval at Xq12-13. ${ }^{7}$ Several candidate genes from this region were proposed and sequence changes were identified in the coding region of connexin 32 (CX32) in seven out of eight CMTX patients. ${ }^{8}$ The demonstration of $C \times 32$ expression in the peripheral nerve ${ }^{8}$ and identification of additional mutations in other CMTX families, ${ }^{9}$ confirmed $C \times 32$ as the causal gene in this form of CMTX, designated CMTX1. 


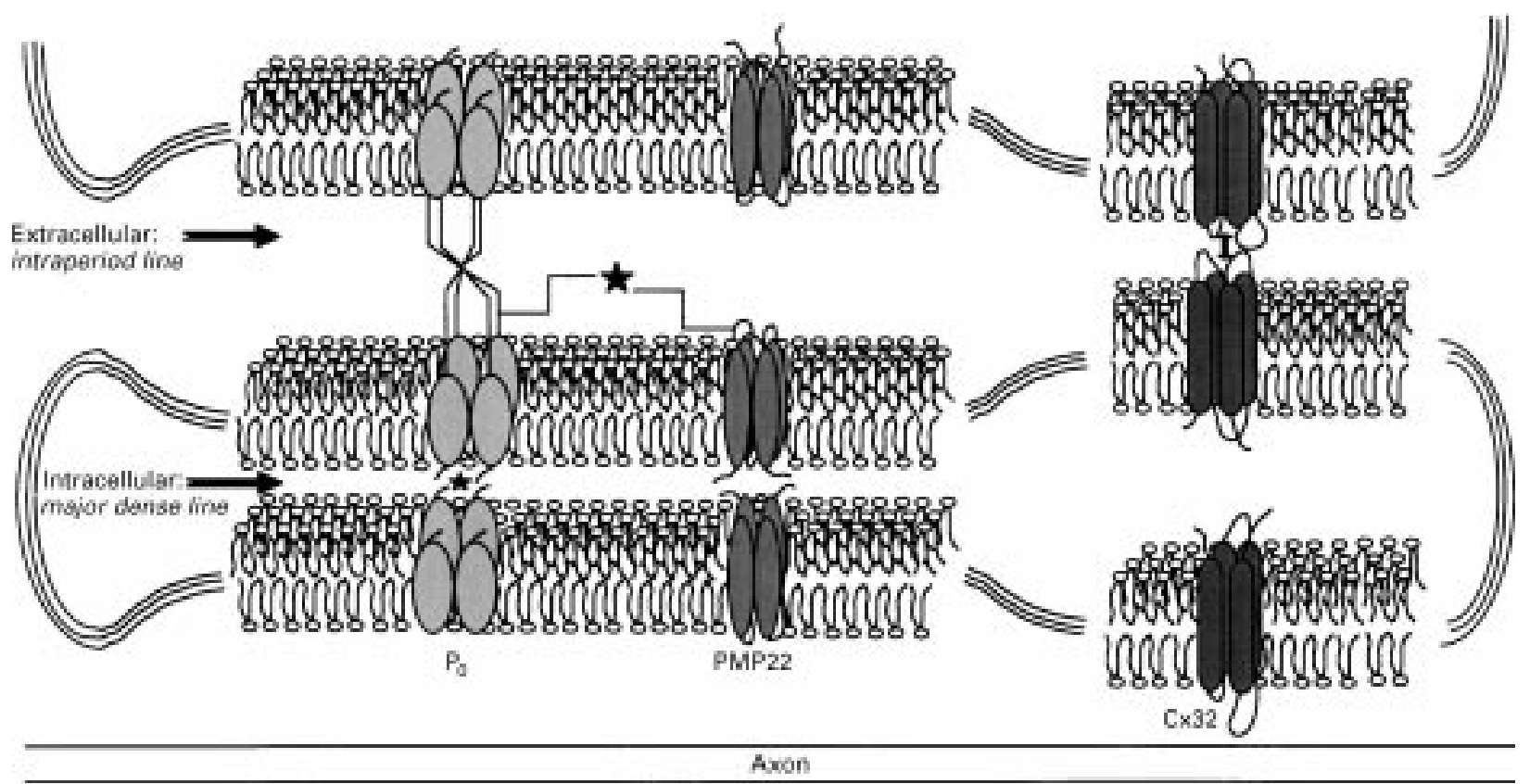

Figure 1 Schematic representation of the distribution of the myelin proteins PMP22, $P_{0}$, and Cx32. PMP22 and $P_{0}$ are both transmembrane proteins located in compact myelin. Cx32, also a transmembrane protein, is located in the non-compact portion of the myelin. The tetrameric arrangement of the $P$ extracellular domains is shown, and the extracellular heterophilic interaction of $P_{0}$ and PMP22 and the homophilic $P_{0}$ interaction are depicted by asterisks. The double headed arrow depicts the hypothesised movement of metabolites through Cx32 between the myelin layers.

OTHER CMT DISEASE LOCI

The recessive forms of CMT disease have received less attention than the dominant forms due, in part, to the observed heterogeneity and subsequent difficulties in defining a clinical phenotype. Several distinct loci have been indicated by linkage studies, but there is currently no evidence to suggest that any of the genes involved in CMT1 or CMTX1 are responsible for either X linked or autosomal recessive cases of CMT disease.

\section{Schwann cell biology}

The CMT disease genes identified to date are expressed in Schwann cells, which associate with axonal elements and wrap layer after layer of themselves around the axon to form the myelin sheaths, thereby enhancing NCVs.

SCHWANN CELL PROLIFERATION AND DIFFERENTIATION Proper Schwann cell development and myelination necessitates Schwann cell proliferation and differentiation, events which have been shown to be induced by axonal contact-an effect mimicked by raised cAMP levels. ${ }^{10}$ Recent evidence has attributed this mitogenic effect of axons to a family of Neu differentiation factors. ${ }^{11}$ Following association with axonal segments, Schwann cell differentiation, that is the expression of myelin genes such as $P_{0}$, $P M P 22$, and $C \times 32$ occurs. However, the key factors involved in the timing of their expression are unknown.

Interestingly PMP22 and Cx32 are expressed in both neural and non-neural cells, facilitated by alternative promoters. $^{12} 13$ Each promoter drives the expression, although not exclusively, of a particular transcript in different cell types. In vitro studies of PMP22 gene expression have shown that both neural and non-neural transcripts are induced to an equal extent by an increase in cAMP. Yet in vivo, myelination is allied with the upregulation of the neural transcript, out of proportion to the non-neural form. ${ }^{12}$ The intrinsic factors involved in this selective control are as yet undefined, although transcription factors similar in effect to Krox-20 and Oct-6, which have been suggested to have a role in early myelinogenesis, ${ }^{11}$ may be involved.
The functional significance of these multiple promoters is unclear but conceivable that they are indicative of alternative functions - perhaps one being related to cell growth in early development, and a second in myelin structural integrity of mature Schwann cells.

\section{FUNCTION OF THE MYELIN PROTEINS}

The myelin proteins MBP, MAG, PMP22, $\mathrm{P}_{0}, \mathrm{Cx} 32$ all play a part in the maintenance of myelin integrity (fig 1), but for the sake of brevity in this article only those associated with CMT disease to date are discussed here. $\mathrm{P}_{0}$ is a major integral myelin membrane protein, traversing the membrane once, and mediates membrane adhesion in the concentric myelin wraps. The adhesive properties of the protein are attributed to the extracellular domain of $P_{0}$ which forms a tetrameric array that interlocks with similar arrangements in the opposing membranes, and a homophilic cytoplasmic interaction. ${ }^{14} \mathrm{P}_{0}$ is also thought to partake in a heterophilic interaction with the transmembrane protein PMP22 via the L2/HNK-1 epitopes of their glycosidic links. ${ }^{15}$ The suggested role of these proteins in the compaction of myelin has been validated by the generation of various knockout mouse models that demonstrate poor myelin compaction, accompanied by axon degeneration and signs of demyelination. ${ }^{16-18}$

In addition to its structural role it has also been suggested that PMP22 plays a part in cellular growth, primarily due to its down regulation after nerve damage. ${ }^{19}$ Whether this is directly related to a cell growth phenomenon or the return to a "dedifferentiated" state of the cell is unknown. However, the role of PMP22 in cellular growth must still be considered, especially in view of the alternative transcript that predominates in non-neural cells.

The gap junction protein $\mathrm{Cx} 32$ has been localised to the paranodal regions and Schmidt-Lantermann incisures of myelin, ${ }^{8}$ and believed to function as a channel for the transport of electrolytes and metabolites between the myelin wraps of an individual cell. This trafficking of molecules is also considered to extend to the axon. 
Effect of myelin gene defects at the phenotypic level OVEREXPRESSION OF PMP22

The most common genotypic defect in CMT disease disease is the duplication of the PMP22 gene and its subsequent overexpression. On peripheral nerve biopsy these patients typically show evidence of demyelination and remyelination, onion bulb formation, and Schwann cell proliferation. Mouse models of the CMT1A phenotype have shown that overexpression is indeed involved, and demonstrate that with an increasing copy number of PMP22 the effects are exaggerated and the phenotype more severe. ${ }^{2021}$ In these cases, it is hypothesised that myelination is initiated, but a breakdown in the process occurs, leading to the continued demyelination and remyelination typical of CMT1. This breakdown in the homoeostatic control may be caused by the inherent overexpression of PMP22, which prevents the cells from differentiating further and in turn, lead to the apoptotic-like cells observed by Fabretti et al..$^{22}$ Alternatively, the hypothesised increased proportion of PMP22 within the cell membrane may upset protein stoichiometry and hence the structural integrity of the myelin, leading to its degeneration. Both hypotheses would account for the observed Schwann cell proliferation as macrophage mediated myelin degeneration has been shown to have such a mitogenic effect. ${ }^{23}$ That no effects are noted in non-neural cells is interesting. Perhaps the effects of this overexpression are not detrimental to the cell, or alternatively, a functionally analogous protein compensates.

\section{UNDEREXPRESSION OF PMP22}

The exaggerated phenotype observed with increasing copy number is conversely duplicated, with a decreasing copy number. Knockout mouse models of PMP22 have shown that the double copy knockout model is more severely affected than the heterozygous mouse. ${ }^{18}$ Although no patients with the deletion of both PMP22 copies have yet been observed, a similar effect would be envisaged.

POINT MUTATION WITHIN THE MYELIN GENES

The effect of this type of defect in PMP22 appears to be more severe than overexpression of the gene, both in human and animal models. Mutations of the $P_{0}$ gene also appear to result in a severe phenotype. Even within this class, a spectrum of phenotypes is observed and considered to be due to the effect of the mutation-whether a loss of, or dominant negative gain of, function is afforded by the corresponding mutant protein, which in turn yields further phenotypic heterogeneity depending on the actual site of the mutation.

The mechanisms by which the defects in PMP22 and $P_{0}$ lead to characteristic CMT1 phenotypes will be similar to that described above. Cx32 defects, on the other hand, have been shown to result in improper gating abilities of the connexin hemichannels, ${ }^{24}$ theoretically leading to deficiencies in intracellular transport of metabolites, and in turn to Schwann cell degeneration and possibly to the observed axonopathy evident in CMTX1 patients.

In contrast to coding region defects of myelin genes, the first evidence of mutations within the promoter sequences (of $C \times 32$ ) has been reported. ${ }^{25}$ One of these mutations is thought to affect the rate of transcription initiation, while the second may create a new splice site motif or alternatively, a new translation start codon. However, the actual effect of these and similar promoter mutations requires further investigation.

\section{Molecular diagnosis and prospects for the future}

The molecular diagnosis of the peripheral neuropathies is a complex procedure and its success depends on various fac-
Key messages

- The duplication of a 1.5 Mb DNA fragment encompassing the PMP22 gene on chromosome $17 \mathrm{p} 11.2$ is associated with over $70 \%$ of CMT1 cases

- Point mutations of the PMP22, $P_{0}$, and $C \times 32$ genes are also associated with the CMT1 phenotype

- PMP22 and $P_{0}$ encode myelin proteins which have important roles in the compaction of myelin. Cx32 encodes a gap junction protein which is considered to allow trafficking of metabolites and secondary messengers between the non-compact layers of myelin. Murine models have validated the hypothesised roles of these proteins

- CMT disease is extremely heterogeneous, with at least eight additional loci identified. No genes have as yet been identified at these loci

tors including knowledge of family history, availability of local clinical testing, and the resources of the diagnostic laboratory. Where possible, clinicians should provide full clinical details including nerve conduction velocities and a detailed family history. Unless there is evidence to suggest a type 2 phenotype, PMP22 duplication testing is the initial screen in CMT disease diagnosis as it accounts for over $70 \%$ of CMT1 cases. If no duplication is observed and there is no recorded male to male inheritance in the patient's family history, then $\mathrm{Cx} 32$ screening follows as this represents the second most common genetic defect in CMT disease to date. Individuals referred with no obvious family history would be investigated likewise.

Mutation screening of $P_{0}$ then $P M P 22$, is the natural next step for patients shown to have no $C \times 32$ defect and/or no observed duplication. However, due to time and monetary constraints of diagnostic laboratories, combined with the somewhat low detection rate, these screens are often only performed within research programmes.

Now that the molecular basis of several neuropathies has been elucidated, research based on this new knowledge can aid in understanding the actual pathogenic mechanisms. Although to date, there is no effective treatment for alleviating the symptoms of CMT disease, these and similar studies will undoubtedly accelerate progress towards the goals of therapeutic medicine. Indeed, a canine model has shown that focally transplanted glial cells are capable of myelinating areas of the central nervous system, ${ }^{26}$ a situation comparable to the focal lesions observed in multiple sclerosis, thus inferring hope for the future in the treatment of multiple sclerosis and other disorders of myelination.

CHRISTINE BELL NEVA HAITES

Medical Genetics,

Department of Medicine and Therapeutics,

Department of Molecular and Cell Biology,

University of Aberdeen Medical School,

Foresterhill, Aberdeen AB25 2ZD

1 Dyck PJ, Lambert EH. Lower motor and primary sensory neuron diseases with peroneal muscular atrophy. Arch Neurol 1968;18:603-18.

2 Dyck PJ, Lambert EH. Lower motor and primary sensory neuron diseases with peroneal muscular atrophy. Arch Neurol 1968;18:618-25.

3 Chance PF, Alderson MF, Leppig KA, et al. DNA deletion associated with hereditary neuropathy with liability to pressure palsies. Cell 1993;72:14351.

4 Patel PI, Lupski JR. Charcot-Marie-Tooth disease: a new paradigm for the mechanism of inherited disease. Trends Genet 1994;10:128-33.

5 Ionasescu VV, Kimura J, Searby CS, Smith Jr WL, Ross MA, Ionasescu R. A Dejerine- Sottas neuropathy family with a gene mapped on chromosome 8. Muscle Nerve 1996;19:319-23.

6 Ionasescu V, Searby C, Sheffield VC, Roklina T, Nishimura D, Ionasescu R. Autosomal dominant Charcot-Marie-Tooth axonal neuropathy mapped on Autosomal dominant Charcot-Marie-Tooth axonal neuropathy
chromosome 7p (CMT2D). Hum Mol Genet 1996;5:1373-5.

7 Pericak-Vance MA, Barker DF, Bergoffen J, et al. Consortium fine localisation of X-linked Charcot-Marie-Tooth disease (CMTX1): additional suption of X-linked Charcot-Marie-Tooth disease (CMTX1): additional sup-
port that connexin32 is the defect in CMTX1. Hum Hered 1995;45:121-8. 
8 Bergoffen J, Scherer SS, Wang S, et al. Connexin mutations in X-linked Charcot-Marie-Tooth disease. Science 1993;262:2039-42.

9 Fairweather N, Bell C, Cochrane S, et al. Mutations in the connexin 32 gene in X-linked Charcot-Marie-Tooth disease (CMTX1). Hum Mol Genet 1994;3:29-31.

10 Pareek S, Suter U, Snipes GJ, Welcher A, Shooter EM, Murphy RA. Detection and processing of peripheral myelin protein PMP22 in cultured Schwann cells. F Biol Chem 1993;268:10372-9.

11 Mirsky R, Jessen K. Schwann cell development, differentiation and myelination. Curr Opin Neurobiol 1996;6:89-96.

12 Suter U, Snipes GJ, Schoener-Scott R, et al. Regulation of tissue specific expression of alternative peripheral myelin protein 22 (PMP22) gene transcripts by two promoters. F Biol Chem 1994;269:25795-808.

13 Sohl G, Gillen C, Bosse F, Gleichmann M, Muller HW, Willecke K. A second alternative transcript of the gap junction gene connexin 32 is expressed in murine Schwann cells and modulated in injured sciatic nerve. Eur $f$ Cell Biol 1996;69:267-75.

14 Shapiro L, Doyle J, Hensley P, Colman DR, Hendrickson WA. Crystal structure of the extracellular domain from $\mathrm{P}_{0}$, the major structural protein structure of the extracellular domain from $\mathrm{P}_{0}$, the major structural protein
of peripheral nerve myelin. Neuron $1996 ; 17: 435-49$.

15 Grifflips $\mathrm{LS}$, Schm

Griffiths LS, Schmitz B, Schachner M. L2/HNK-1 carbohydrate and protein-protein interactions mediate the homophilic binding of the neural adhesion molecule $\mathrm{P}_{0}$. F Neurosci Res 1992,33.639-48.

16 Giese KP, Martini R, Lemke G, Soriano P, Schachner M. Mouse $P_{0}$ gene disruption leads to hypomyelination, abnormal expression of recognition molecules, and degeneration of myelin and axons. Cell 1992;71:565-76.

17 Martini R, Mohajeri MH, Kasper S, Giese KP, Schachner M. Mice doubly deficient in the genes for $\mathrm{P}_{0}$ and myelin basic protein show that both proteins contribute to the formation of the major dense line in peripheral nerve myelin. f Neurosci 1995; 15:4488-98.
18 Adlkofer K, Martini R, Aguzzi A, Zieslak J, Toyka KV, Suter U. Hypermyelination and demyelinating peripheral neuropathy in PMP22-deficient mice. Nat Genet 1995;11:274-80

19 Spreyer P, Kuhn G, Hanemann CO, et al. Axon-regulated expression of a Schwann cell transcript that is homologous to a "growth arrest-specific" gene. EMBO f 1991;10:3661-8.

20 Huxley C, Passage E, Manson A, et al. Construction of a mouse model of Charcot-Marie-Tooth disease type $1 \mathrm{~A}$ by pronuclear injection of human YAC DNA. Hum Mol Genet 1996;5:563-9.

21 Magyar JP, Martini R, Ruelicke T, et al. Impaired differentiation of Schwann cells in transgenic mice with increased PMP22 gene dosage. 7 Neurosci 1996;16:5351-60.

22 Fabretti E, Edomi P, Brancolini C, Schneider C. Apoptotic phenotype induced by overexpression of wild type gas3/PMP22: its relation to the demyelinating peripheral neuropathy CMT1A. Genes Dev 1995;9:184656.

23 Baichwal, R Bigbee JW, deVries GH. Macrophage-mediated myelin-related mitogenic factor for cultured Schwann cells. Proc Natl Acad Sci U S A 1988;85:1701-5.

24 Bruzzone R, White TW, Paul DL. Expression of chimeric connexins reveals new properties of the formation and gating behaviour of gap junction channels. F Cell Sci 1994;107:955-67.

25 Ionasescu VV, Searby BS, Ionasescu R, Neuhaus IM, Werner R. Mutations of the noncoding region of the connexin 32 gene in X-linked dominant Charcot-Marie-Tooth neuropathy. Neurology 1996;47:541-4.

26 Archer DR, Cuddon PA, Lipsitz D, Duncan ID. Myelination of the canine central nervous system by glial cell transplantation: a model for repair of human myelin disease. Nat Med 1996;3:54-9. 